\title{
Outdoor dining causing blisters: think infantile phytophotodermatitis
}

\author{
Berbie Byrne, Waqas Mahmood, Bart Ramsay, Kashif Ahmad
}

Dermatology, University Hospital Limerick, Limerick, Ireland

\section{Correspondence to \\ Dr Berbie Byrne; \\ berbie.byrne@hse.ie}

Accepted 11 April 2021

\section{DESCRIPTION}

A 5-month-old boy was brought to the emergency department in June by his mother, with a 1-day history of a progressive erythematous rash on his face, chest and hands with associated blistering (figure 1). The child was systemically well with no medical history. Detailed history revealed that a day before admission, he had been feeding himself mashed carrots and parsnips while sitting outside in the sunshine wearing only a nappy. As he was a 'messy' eater and it was very sunny, he subsequently had his bath outside. His parents first noticed the rash on his right hand the next morning. It progressed during the day to his left hand, face and midchest. By evening, he had developed blisters on his right hand.

On examination, he had a well demarcated, erythematous rash with erosions distributed periorally, centrally on the chest and upper abdomen with small irregular patches on his thighs and shoulders. On his right hand, there were large tense bullae and areas of desquamation (figure 1). The rash was associated with perioral erythema and peripheral streaks in a bizarre configuration consistent with a linear drip pattern (figure 2). There was sparing of his posterior trunk, mucus membranes, palms and soles. Phytophotodermatitis was diagnosed based on the history of outdoor eating in sunshine and the streaky appearance of the rash in a distribution where psoralen containing food came into contact with his skin. The patient responded to treatment with topical betamethasone $0.025 \%$ to his chest and limbs, and hydrocortisone $1 \%$ to his face. The

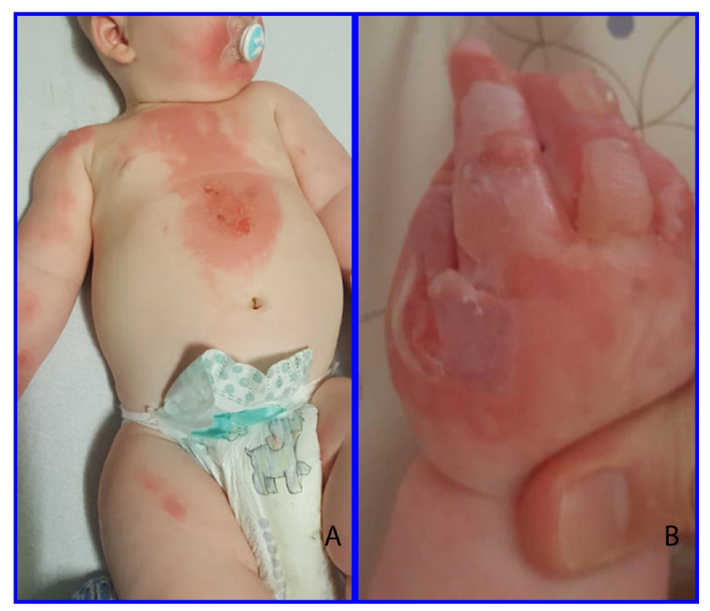

Figure 1 Presentation to accident and emergency, rash day 2. (A) Erythematous rash with superficial erosion. (B) Bulla and linear vesiculobullous eruption, right hand.

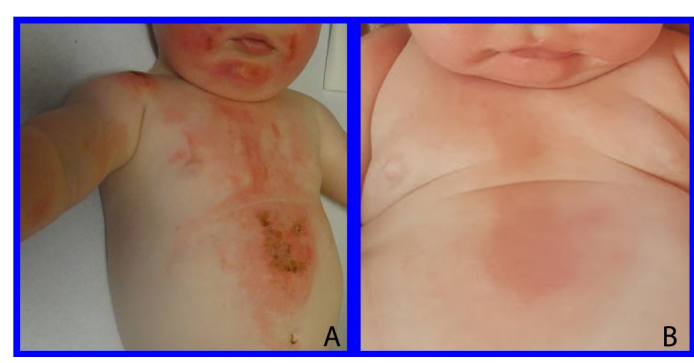

Figure 2 (A) Rash day 5. Perioral erythema on the face. Irregular patches on the chest with peripheral linear streaks in a bizarre configuration. (B) Mild residual hyperpigmentation remains.

rash resolved with mild residual hyperpigmentation (figure 2).

Phytophotodermatitis presents with erythema and bullae in an eccentric linear streaky configuration on sun-exposed skin reflecting contact with the psoralen source. ${ }^{12}$ It is an important diagnosis as it can masquerade as abuse. ${ }^{3}$ Rash characteristics can range from erythema, vesicles or bullae, often healing with hyperpigmentation. ${ }^{2}{ }^{4}$ The eruption

\section{Patient's perspective}

Seeing my son covered in burns was so traumatic for our family. We hope by sharing his case that others will get a quick diagnosis like we did. We were so fortunate that he had a fantastic team caring for him and we received a timely diagnosis and treatment, and as a result, he has been left with no permanent damage, something we were so worried about at the time (statement from the patient's mother).

\section{Learning points}

- Phytophotodermatitis should be suspected when an infant presents with an acute, vesiculobullous eruption in a linear pattern after exposure to sunlight and a psoralen-containing substance such as carrots and parsnips.

- Phytophotodermatitis is a clinical diagnosis. Key to diagnosis is a comprehensive history, focusing on skin exposure to a psoralen and ultraviolet light, coupled with a heightened awareness, especially when there has been recent fine weather.

- The clinician must be aware that this entity exists to avoid misdiagnosis. 
occurs within 24 hours of ultraviolet exposure and peaks at 48-72 hours. ${ }^{5}$ The lesions have unusual shapes and are often painful but not pruritic and appear only in sun-exposed areas. ${ }^{6}$ Common culprits are giant hogweed, celery and parsley but there are reports of citrus fruits, carrots, parsnip and fennel. ${ }^{4}$ Due to the bizarre configurations of lesions, phytophotodermatitis mimics a variety of different diseases. Differential diagnosis includes polymorphic light eruption, severe sun burn, staphylococcal scalded syndrome, contact dermatitis, infectious exanthema, drug-related rash and non-accidental injury. ${ }^{3}$

Acknowledgements Thank you to the dermatology staff, especially Aisling O'Shaughnessy, clinical nurse specialist at University Hospital Limerick, for the dedicated care provided to our patients on a daily basis.

Contributors BB: Performed literature review of phytophotodermatitis. Interviewed patient's mother regarding patient presentation. Primary author of the case report under the guidance of KA and BR. Edited case report until final version approved for submission. WM: Assisted in literature review of phytophotodermatitis and reviewing medical chart and emergency department notes. Reviewed laboratory and microbiology results. Involved in editing of photos and photo design. BR: Reviewed initial case report and provided recommendations on improvements. Final approval of submitted case report. KA: Consultant who initially diagnosed the patient. Involved in discussion of case, including clinical signs, differential diagnosis and treatment plan. Reviewed multiple drafts of the case report and provided approval of final draft.

Funding The authors have not declared a specific grant for this research from any funding agency in the public, commercial or not-for-profit sectors.

Competing interests None declared.

Patient consent for publication Parental/guardian consent obtained.

Provenance and peer review Not commissioned; externally peer-reviewed.

\section{REFERENCES}

1 Raam R, DeClerck B, Jhun P, et al. Phytophotodermatitis: The Other "Lime" Disease. Ann Emerg Med 2016;67:554-6.

2 Moreau JF, English JC, Gehris RP. Phytophotodermatitis. J Pediatr Adolesc Gynecol 2014;27:93-4.

3 Carlsen K, Weismann K. Phytophotodermatitis in 19 children admitted to hospital and their differential diagnoses: child abuse and herpes simplex virus infection. J Am Acad Dermatol 2007:57:S88-91.

4 Harshman J, Quan Y, Hsiang D. Phytophotodermatitis: rash with many faces. Can Fam Physician 2017;63:938

5 Sasseville D. Clinical patterns of phytodermatitis. Dermatol Clin 2009;27:299-308.

6 Shah N, Khachemoune A. What is this streaky rash? JAAPA 2014;27:18-19.

Copyright 2021 BMJ Publishing Group. All rights reserved. For permission to reuse any of this content visit https://www.bmj.com/company/products-services/rights-and-licensing/permissions/

BMJ Case Report Fellows may re-use this article for personal use and teaching without any further permission.

Become a Fellow of BMJ Case Reports today and you can:

- Submit as many cases as you like

Enjoy fast sympathetic peer review and rapid publication of accepted articles

- Access all the published articles

- Re-use any of the published material for personal use and teaching without further permission

Customer Service

If you have any further queries about your subscription, please contact our customer services team on +44 (0) 2071111105 or via email at support@bmj.com.

Visit casereports.bmj.com for more articles like this and to become a Fellow 